\title{
Altered Gut Structure and Anti-Bacterial Defense in Adult Mice Treated with Antibiotics during Early Life
}

\author{
Tânia Martins Garcia ${ }^{1}$, Manon van Roest ${ }^{1}$, Jacqueline L. M. Vermeulen ${ }^{1}$, Sander Meisner ${ }^{1}$, Jan $\operatorname{Koster}^{2} \mathbb{D}$, \\ Manon E. Wildenberg ${ }^{1}$, Ruurd M. van Elburg ${ }^{3}{ }^{(1)}$, Vanesa Muncan ${ }^{1, *, \dagger}$ and Ingrid B. Renes ${ }^{3,4,+}$
}

1 Department of Gastroenterology and Hepatology, Tytgat Institute for Intestinal and Liver Research, Amsterdam UMC, AGEM, University of Amsterdam, 1105 BK Amsterdam, The Netherlands; t.martinsgarcia@amsterdamumc.nl (T.M.G.); m.vanroest@amsterdamumc.nl (M.v.R.); j.l.vermeulen@amsterdamumc.nl (J.L.M.V.); s.meisner@amsterdamumc.nl (S.M.); m.e.wildenberg@amsterdamumc.nl (M.E.W.)

2 Laboratory for Experimental Oncology and Radiobiology, Center for Experimental and Molecular Medicine, Amsterdam University Medical Centers, University of Amsterdam, Cancer Center Amsterdam, 1105 AZ Amsterdam, The Netherlands; jankoster@amsterdamumc.nl

3 Department of Pediatrics, Amsterdam UMC, University of Amsterdam, 1105 AZ Amsterdam, The Netherlands; rm.vanelburg@amsterdamumc.nl (R.M.v.E.); ingrid.renes@danone.com (I.B.R.)

4 Danone Nutricia Research, 3584 CT Utrecht, The Netherlands

* Correspondence: v.muncan@amsterdamumc.nl

+ These authors contributed equally to this work.

\section{check for}

updates

Citation: Martins Garcia, T.;

van Roest, M.; Vermeulen, J.L.M.;

Meisner, S.; Koster, J.; Wildenberg,

M.E.; van Elburg, R.M.; Muncan, V.;

Renes, I.B. Altered Gut Structure and

Anti-Bacterial Defense in Adult Mice

Treated with Antibiotics during Early

Life. Antibiotics 2022, 11, 267.

https://doi.org/10.3390/

antibiotics11020267

Academic Editor: Marc Maresca

Received: 2 January 2022

Accepted: 16 February 2022

Published: 18 February 2022

Publisher's Note: MDPI stays neutral with regard to jurisdictional claims in published maps and institutional affiliations.

Copyright: (C) 2022 by the authors. Licensee MDPI, Basel, Switzerland. This article is an open access article distributed under the terms and conditions of the Creative Commons Attribution (CC BY) license (https:// creativecommons.org/licenses/by/ $4.0 /$ )

\begin{abstract}
The association between prolonged antibiotic $(\mathrm{AB})$ use in neonates and increased incidence of later life diseases is not yet fully understood. AB treatment in early life alters intestinal epithelial cell composition, functioning, and maturation, which could be the basis for later life health effects. Here, we investigated whether AB-induced changes in the neonatal gut persisted up to adulthood and whether early life $\mathrm{AB}$ had additional long-term consequences for gut functioning. Mice received $\mathrm{AB}$ orally from postnatal day 10 to 20. Intestinal morphology, permeability, and gene and protein expression at 8 weeks were analyzed. Our data showed that the majority of the early life AB-induced gut effects did not persist into adulthood, yet early life AB did impact later life gut functioning. Specifically, the proximal small intestine (SI) of adult mice treated with AB in early life was characterized by hyperproliferative crypts, increased number of Paneth cells, and alterations in enteroendocrine cell-specific gene expression profiles. The distal SI of adult mice displayed a reduced expression of antibacterial defense markers. Together, our results suggest that early life AB leads to structural and physiological changes in the adult gut, which may contribute to disease development when homeostatic conditions are under challenge.
\end{abstract}

Keywords: antibiotics; early life; long-term; small intestine; bacterial defense

\section{Introduction}

Early life is a crucial moment in the development of mammals. Events that occur during the first weeks or months after birth can imprint long-lasting effects [1-4]. Among the external factors that can affect long-term health are early life antibiotics (AB). $A B$ are commonly prescribed to neonates and children [5-7] due to the high incidence of respiratory infections in pediatric patients [8]. Furthermore, early life AB are used to treat gastrointestinal, skin, and ear infections. Many neonates also receive AB because of suspected early onset sepsis, especially after preterm birth [9]. However, in most cases, bacterial infection is not culture proven in uninfected infants [10]. Especially in the case of premature neonates, $\mathrm{AB}$ are used to treat sepsis or to prevent infection when newborn or maternal risk factors are present. Among the different classes of $A B$, the most used during 
early life are $\beta$-lactams (amoxicillin, ampicillin), aminoglycosides (gentamycin, amikacin), glycopeptides (vancomycin, teicoplanin), and nitroimidazoles (metronidazole).

In recent years, prolonged treatment with early life $\mathrm{AB}$ in humans has been linked with several pathologies later in life, such as obesity [11-14], diabetes [15,16], and inflammatory bowel diseases (IBD) [17-19]. As the gut is home to trillions of commensal bacteria, essential to the balanced functioning of an organism, it is not surprising that the disruption of the microbiome by $\mathrm{AB}$ can lead to gut-related pathologies. In preclinical mouse models, it has been shown that $\mathrm{AB}$ treatment in early life leads to changes in both gut microbiome and intestinal immunity that persist into adulthood, long after the treatment has stopped [20,21]. Moreover, the maturation of the intestinal epithelium is only completed after birth and alterations during this vulnerable period can disturb the normal maturation process and might lead to long-term consequences. We have recently demonstrated that antibiotic treatment during early life can directly affect the intestinal epithelial cell (IEC) composition and functioning, independent of the effects on the microbiome [22]. Pups treated with AB between P10 and P20 showed accelerated intestinal maturation, as demonstrated by the decrease in intestinal permeability and the disappearance of specialized vacuolated cells, characteristic of the neonatal period. Furthermore, in vivo AB treatment of neonatal pups and in vitro $A B$ treatment of fetal intestinal organoids induced the expression of adult specific brush-border enzymes, in both proximal and distal SI, and enteroendocrine cell (EEC) markers, particularly in the proximal SI [22]. Finally, AB-treated pups displayed higher expression of innate defense markers, especially in the distal SI [22]. Previous studies have also shown that adult mice that received $\mathrm{AB}$ during weaning are more susceptible to intestinal colitis and colon cancer when challenged with DSS and/or azoxymethane [23-26]. Altogether, these data suggest that the direct and indirect effects of $A B$ on the immature neonatal gut can have long-lasting consequences and predispose to gut related diseases. Yet, the long-term effects of early life $\mathrm{AB}$ observed in the homeostatic gut, i.e., without any challenge, have never been described. Therefore, it is essential to identify the direct impact of early life $\mathrm{AB}$ on gut development and later life gut functioning in order to better target gut health and prevent diseases.

In the current study, we investigated whether the epithelial changes resulting from the direct effect of $\mathrm{AB}$ early in life, i.e., before and during weaning, persist in the adult intestine. Mice were treated between postnatal days 10 and 20 with amoxicillin, vancomycin, and metronidazole. At 8 weeks of age small intestinal morphology, permeability, and proliferation were analyzed. The expression of small intestinal epithelial genes and proteins previously shown to be directly affected by $A B$ in early life was investigated. Furthermore, by analyzing the global expression of adult IECs we identified additional long-term consequences of $\mathrm{AB}$ in early life.

\section{Results}

\subsection{Adult Mice Treated with Early Life Antibiotics Show Altered Small Intestine Morphology}

To investigate the long-term effects of early life $A B$, we treated mice daily by oral gavage, from postnatal day (P) 10 to $\mathrm{P} 20$, with a mix of $\mathrm{AB}$ comprising the most commonly used classes in neonates: amoxicillin, vancomycin, and metronidazole (Figure 1A). No aminoglycoside $\mathrm{AB}$ was used as this class is not absorbed by the gastrointestinal epithelial cells. At P20, AB treatment ended and mice were weaned (Figure 1A). As of week 3, bodyweight was similar between AB-treated mice and control mice, which received PBS (Figure 1B). We previously showed that the intestinal permeability of P20 pups treated with the same early life $\mathrm{AB}$ mix was reduced compared to control pups [22]. To evaluate whether this difference in intestinal permeability persists into adulthood, we orally administered FITC-dextran to 8-week-old mice, that had been treated with AB in early life, and quantified its concentration in serum four hours later (Figure 1C). The FITC-dextran serum concentration was identical in $\mathrm{AB}$-treated and control mice indicating that intestinal permeability normalized over time after AB treatment (Figure 1D). Still, analysis of the small intestine (SI) showed that both its weight and length were significantly higher in mice that received 
early life AB compared to control mice (Figure 1E,F). Finally, the liver weight of AB-treated mice was significantly lower than control mice, while spleen weight was not different between both groups (Figure 1G,H). Although the differences in intestinal permeability immediately after AB treatment are no longer present in adulthood, the increased weight and length of the SI suggest that early life AB have long-lasting effects on the intestine.

A
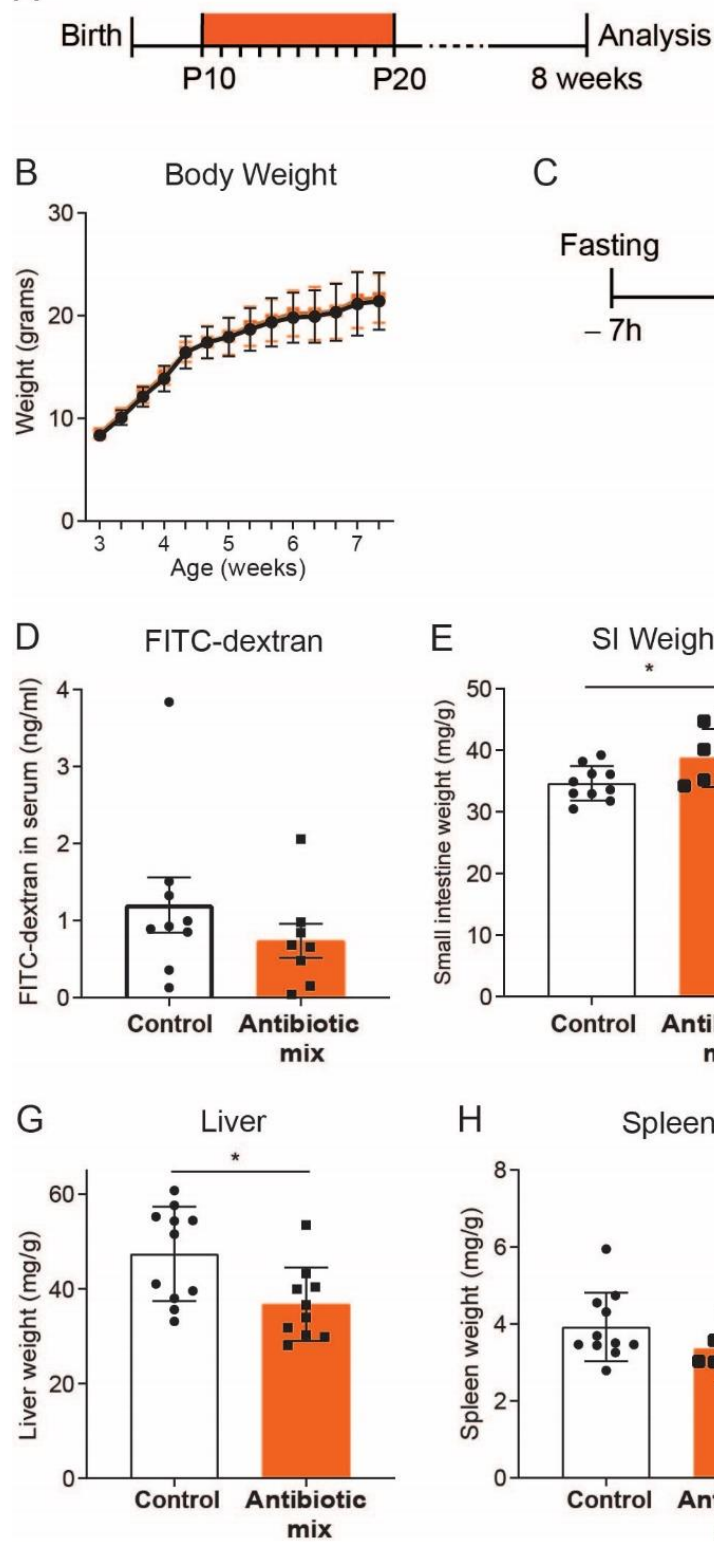

C
Control - PBS

Antibiotic mix - amoxicillin vancomycin metronidazole
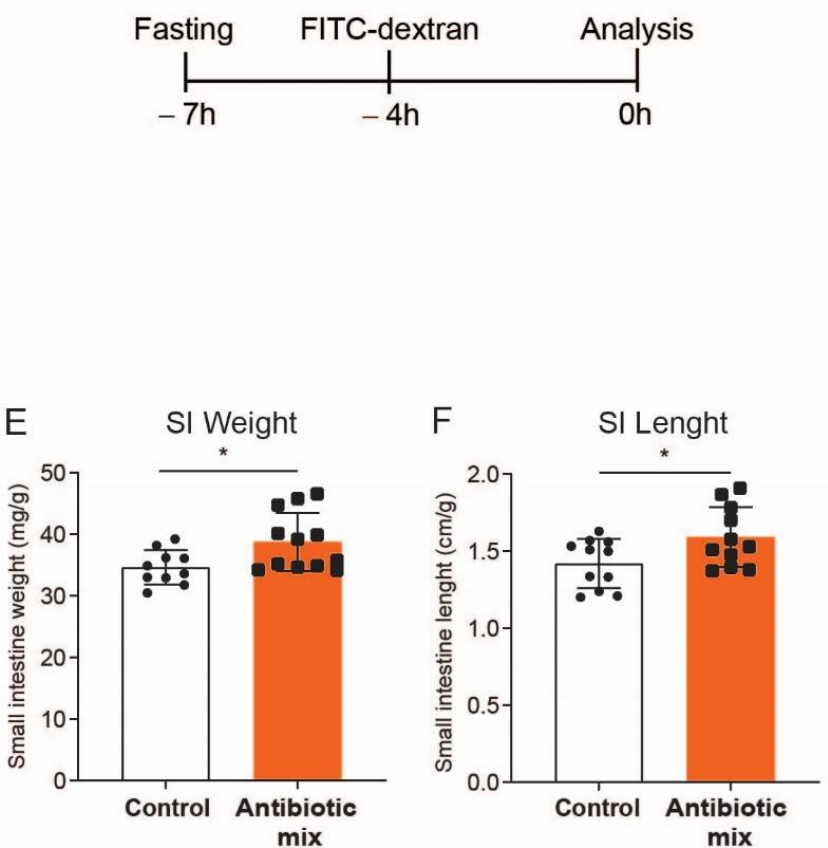

Figure 1. Growth, intestinal permeability, and macroscopic assessment of small intestine, liver, and spleen. (A) Experimental design of in vivo antibiotic treatment of pups between postnatal (P) day 10 and P20. Antibiotic mix: amoxicillin, metronidazole, and vancomycin. All analyses were carried out at 8 weeks of age. (B) Mice weight was measured three times per week after antibiotic mix treatment, $n=11$ control mice, $n=12$ AB-treated mice. (C,D) Permeability assay assessed by FITC-dextran concentration in serum $4 \mathrm{~h}$ after oral gavage, $n=9$ control mice, $n=8$ AB-treated mice. (E) Small intestine weight, relative to body weight, $n=10$ control mice, $n=12$ AB-treated mice. (F) Small intestine length, relative to body weight, $n=11$ control mice, $n=11$ AB-treated mice. (G) Liver weight, relative to body weight, $n=11$ control mice, $n=10$ AB-treated mice. $(\mathbf{H})$ Spleen weight, relative to body weight, $n=11$ control mice, $n=11$ AB-treated mice. Statistical analysis was performed by two-way ANOVA test with Sidak's multiple comparisons test (B) or two-tailed unpaired $t$-test (D-H). Error bars indicate mean $\pm \mathrm{SD}$. Levels of significance are indicated $(* p<0.05)$. 


\subsection{Early Life Antibiotics Induce Hyperproliferative Crypts in Adult Proximal Small Intestine}

The epithelial cells of the proximal and distal SI have different genetic profiles that support specific regional nutrient absorption and digestion functions, as well as different immune defense requirements [27-30]. We previously showed that these two SI regions are differently affected by early life AB treatment at P20 [22]; thus in the present study, we analyzed adult proximal and distal SI separately. Assessment of SI histology revealed no major morphological differences (Figure 2A). A trend towards shorter villi and significantly longer crypts was observed in the proximal SI of AB-treated mice compared to control mice, while distal SI showed similar villus lengths and crypt depths in the two groups (Figure 2B,C). As longer crypts suggest increased proliferation, we performed staining for the mitotic marker phosphorylated histone H3 (PHH3) (Figure 2D). Proximal SI of AB-treated mice displayed a higher number of PHHH3-stained cells compared to control mice and in the distal SI of these mice only, a trend toward increased PHHH3-stained cells was noted (Figure 2E). These results indicate that early life AB induce hyperproliferative crypts in the proximal SI.

\subsection{The Majority of the Direct Effects Induced by Antibiotics on the Neonatal Small Intestine Do Not Persist into Adulthood}

The postnatal maturation of the mouse intestinal epithelium is characterized by several changes in its morphology and function. For example, from P14 to P28, the SI brush-border starts to express adult-specific enzymes, while the number of Paneth cells expands in the newly developed crypts [31]. We have shown that AB treatment of mice between P10 and P20 led to upregulation of the adult brush-border enzymes and Paneth cells at P20 [22]. We also demonstrated that these changes resulted from the direct effect of $A B$ on IECs [22]. Thus, here we set out to determine whether these effects were still present in adult mice that received the same $\mathrm{AB}$ treatment in early life. In contrast with the observations at P20, whole tissue qRT-PCR analysis on the adult proximal SI showed similar relative expression of the brush-border enzymes Sis and Arg2 between AB-treated mice and control adult mice (Figure 3A). However, the relative expression of the Paneth cell marker lysozyme-1 (Lyz1) was higher in AB-treated adult mice compared to control mice (Figure 3A). Immunohistochemistry of Lyz1 also revealed a significantly higher number of Paneth cells in the adult proximal SI after early life AB treatment (Figure 3B). In the distal SI, Arg2 showed a trend towards an increased relative expression after AB treatment, but Sis and Lyz1 were similarly expressed between the two groups (Figure 3C). In accordance, immunohistochemistry of Lyz1 showed a similar amount of Paneth cells in the distal SI in both groups (Figure 3D).

The upregulation of EEC markers observed after AB treatment in proximal SI at P20 did not persist into adulthood, as measured by qRT-PCR of 8-week-old SI whole tissue (Figure 3E). Only the relative expression of secretin (Sct) remained significantly higher, while cholecystokinin (Cck), which relative expression was not changed by AB at P20, was significantly lower in AB-treated adult mice compared to control mice (Figure 3E).

Overall, the adult SI recovered from the direct effects of early life AB treatment, with the exception of the greater number of Paneth cells, the higher relative expression of Sct, and the lower relative expression of Cck in the proximal SI.

\subsection{Genome-Wide Gene Expression Analysis Reveals Modest Differences in Epithelial Cells of Adult Mice Treated with Antibiotics in Early Life}

Early life AB treatment broadly depletes the commensal microbiota of the developing gut, which affects the IECs gene expression profile in early life [13,20,23,24,32]. The unbalanced microbiota expansion that follows after the AB treatment at P20 can also affect IEC-specific gene expression. To examine whether the AB-induced changes in IEC gene expression persist into adulthood, we next performed genome-wide gene expression analysis on mRNA from proximal and distal SI epithelial cells of 8-week-old mice that had received AB or PBS in early life (Figure 4A). Principal component analysis (PCA) showed a modest 
separation between AB-treated and control proximal SI epithelial cells along the second component (PC2 23.1\%) (Figure 4B). This separation was not found in the analysis of distal SI epithelial cells (Figure 4C). Nevertheless, differential gene expression analysis showed a similar number of at least 2-fold upregulated or downregulated genes in AB-treated epithelial cells from both regions (Figure 4D,E). Specifically, 92 genes in proximal SI and 137 genes in distal SI epithelial cells were upregulated. Next, we grouped these differently expressed genes into specific functions. This resulted in a single function being clearly affected specifically in the distal SI: "antibacterial defense". These data showed that, of the few differences in adult IECs gene expression caused by AB treatment in early life, "antibacterial defense" seems to be the only function affected especially in the distal SI.
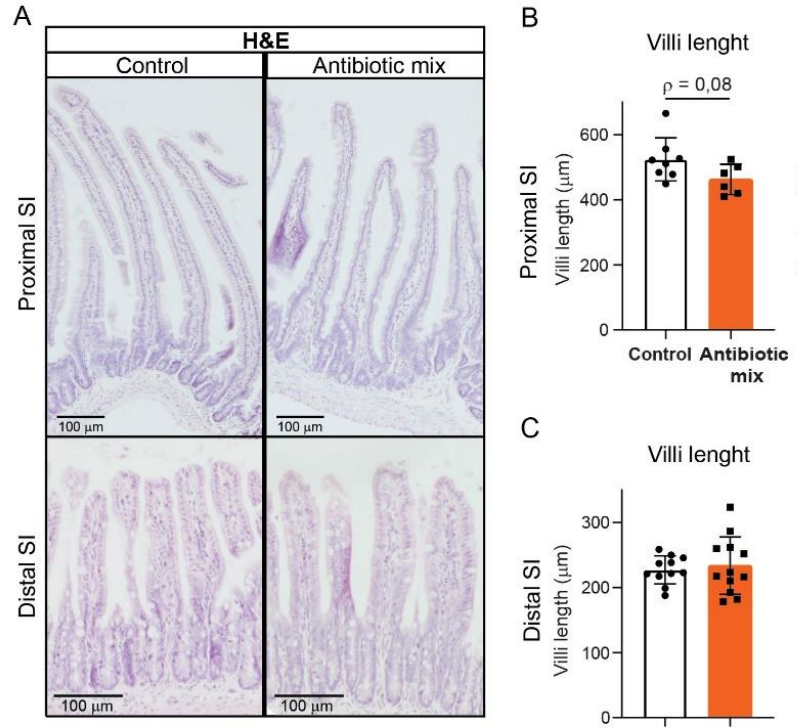

C

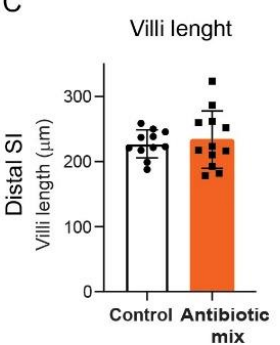

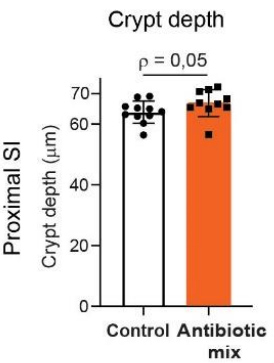

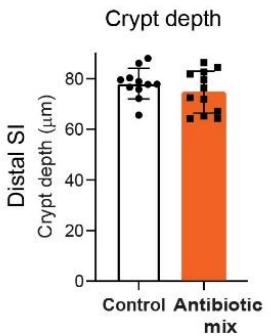

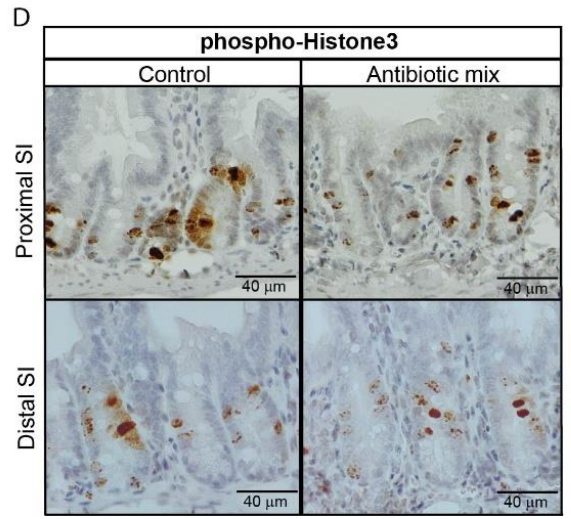

E
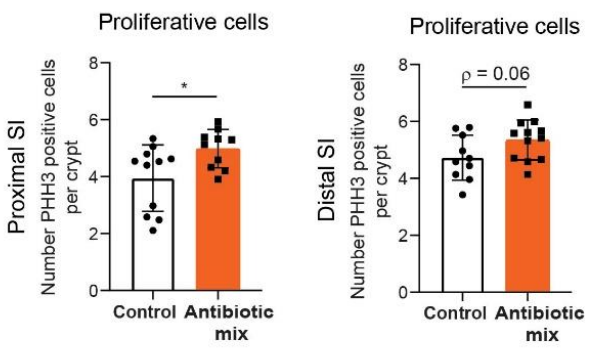

Figure 2. Hyperpoliferative crypts in adult mice treated with early life antibiotics. (A) H\&E staining of proximal and distal small intestine. (Scale bars, $100 \mu \mathrm{m}$.) (B) Villus length and crypt depth in proximal small intestine. Villus: $n=8$ control mice, $n=6$ AB-treated mice; crypt: $n=11$ control mice, $n=10$ AB-treated mice. (C) Villus length and crypt depth in distal small intestine. Villus: $n=11$ control mice, $n=12$ AB-treated mice; crypt: $n=11$ control mice, $n=12$ AB-treated mice. (D,E) Immunohistochemistry of proliferation marker phosphorylated histone H3 (D) and quantifications of positive-stained cells (E) in proximal and distal small intestine. Proximal: $n=11$ control mice, $n=10$ AB-treated mice; distal: $n=10$ control mice, $n=12$ AB-treated mice. (Scale bars, $40 \mu \mathrm{m}$.) Statistical analysis was performed by Mann-Whitney test when data were not normally distributed as assessed by D'Agostino and Pearson normality test $(\mathbf{B})$ or two-tailed unpaired $t$-test $(\mathbf{C}, \mathbf{E})$. Error bars indicate the mean $\pm \mathrm{SD}$. Levels of significance are indicated $(* p<0.05)$. 

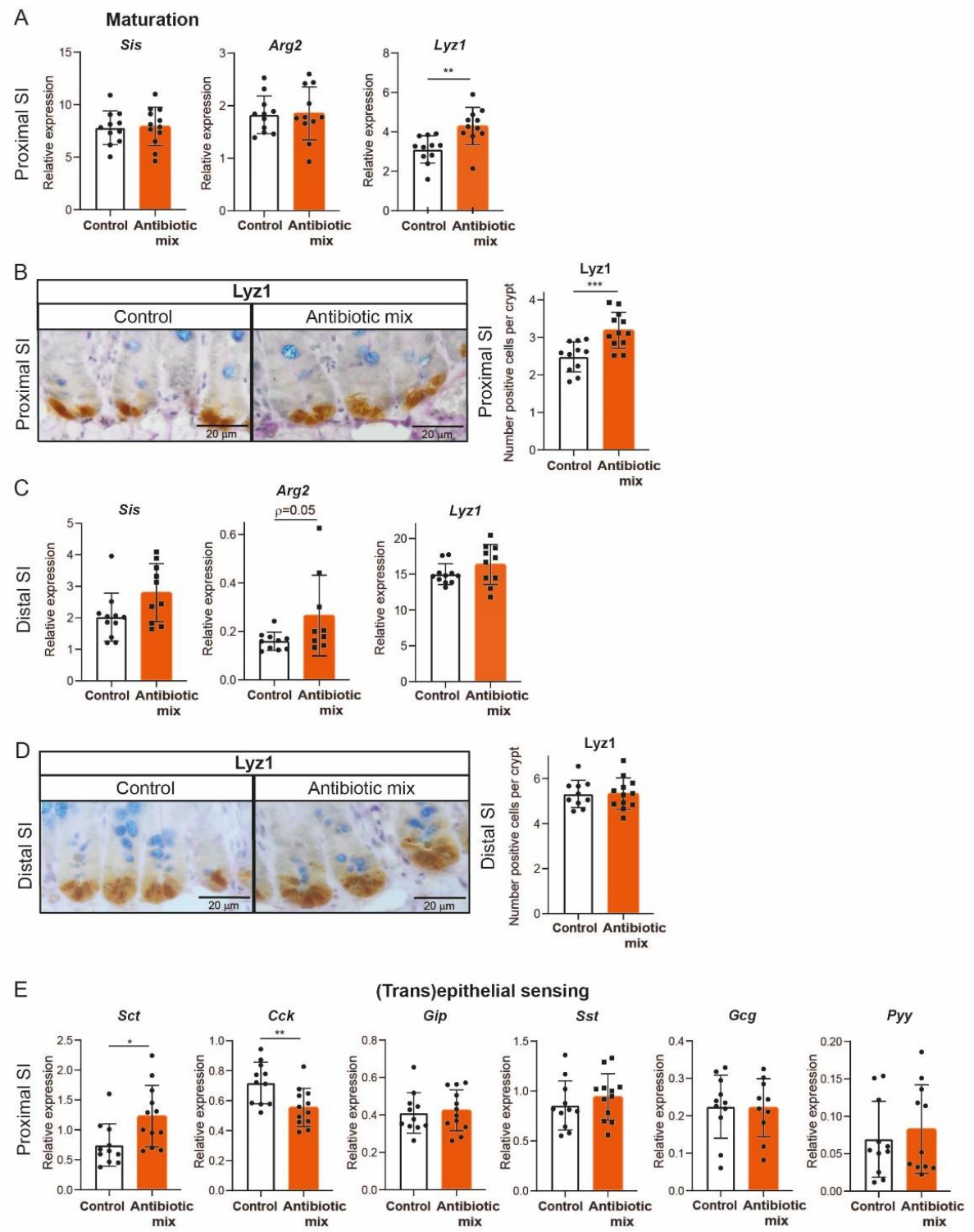

Figure 3. Antibiotics in early life lead to higher number of Paneth cells and few changes in enteroendocrine markers in the proximal small intestine. (A) Whole tissue real-time qPCR analysis of adult brush-border enzymes Sis and Arg2 and of Paneth cell marker Lyz1 in proximal small intestine. Relative expression to reference genes Rpl4 and Ppib. Sis: $n=11$ control mice, $n=12$ AB-treated mice; Arg2: $n=11$ control mice, $n=11$ AB-treated mice; Lyz1: $n=11$ control mice, $n=10$ AB-treated mice. (B) Immunohistochemistry of lysozyme- 1 in proximal small intestine, $n=11$ control mice, $n=12$ AB-treated mice. (Scale bars, $20 \mu \mathrm{m}$.) (C) Whole tissue real-time qPCR analysis of adult brush-border enzymes Sis and Arg2 and of Paneth cell marker Lyz1 in distal small intestine. Relative expression to reference genes Rpl4 and Ppib. Sis: $n=11$ control mice, $n=10$ AB-treated mice; Arg2: $n=10$ control mice, $n=9$ AB-treated mice; Lyz1: $n=11$ control mice, $n=10$ AB-treated mice. (D) Immunohistochemistry of lysozyme- 1 in distal small intestine, $n=10$ control mice, $n=12$ AB-treated mice (Scale bars, $20 \mu \mathrm{m}$.) (E) Whole tissue real-time qPCR analysis of enteroendocrine markers Sct, Cck, Gip, Sst, Gcg, and Pyy in proximal small intestine. Relative expression to reference genes Rpl4 and Ppib. Sct, Cck, Gip, Sst: $n=11$ control mice, $n=12$ AB-treated mice. Gcg: $n=11$ control mice, $n=10$ AB-treated mice. Pyy: $n=11$ control mice, $n=11$ AB-treated mice. Statistical analysis was performed by one-tailed unpaired $t$-test or by Mann-Whitney test when data were not normally distributed as assessed by D'Agostino and Pearson normality test (Sct). Error bars indicate the mean $\pm \mathrm{SD}$. Levels of significance are indicated $\left({ }^{*} p<0.05,{ }^{* *} p<0.01,{ }^{* * *} p<0.005\right)$. 


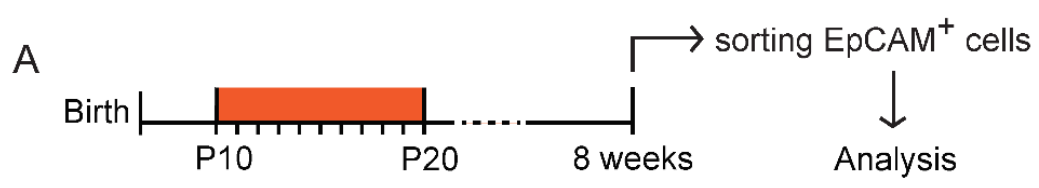

B

Proximal contro

Proximal antibiotic mix
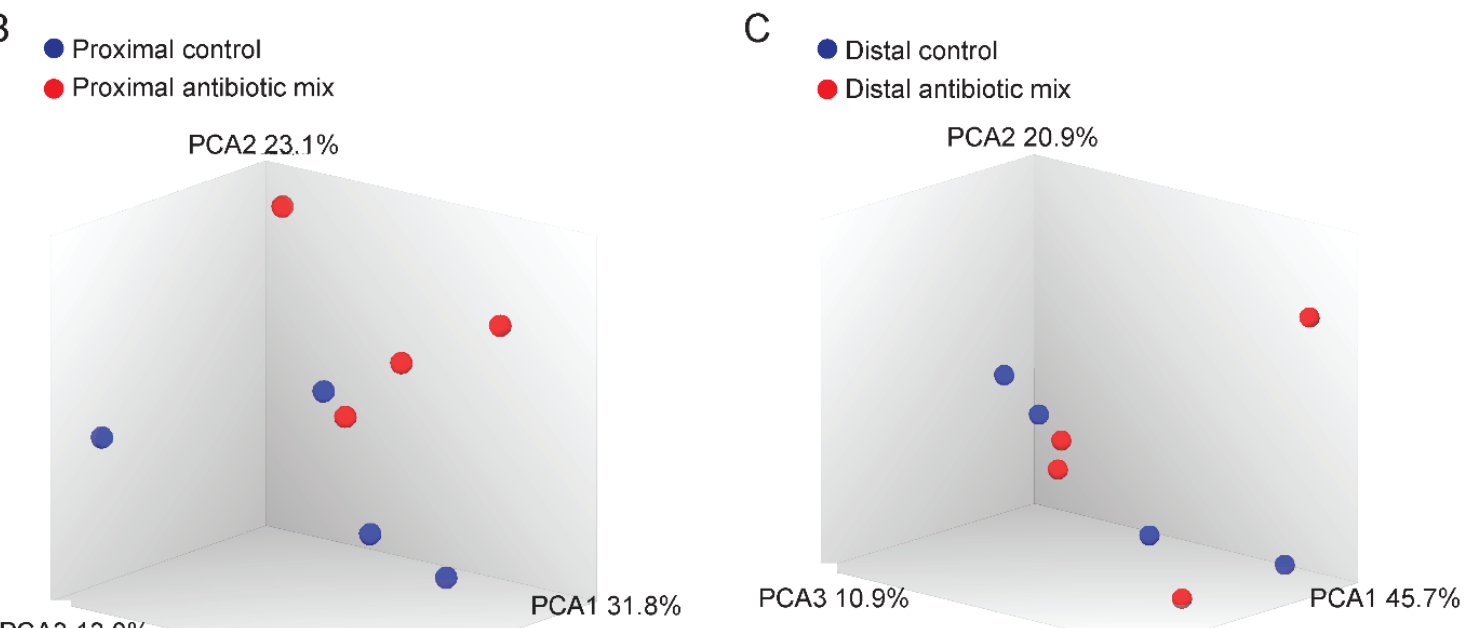

PCA3 $13.0 \%$

PCA1 $31.8 \%$

E

Distal SI

p-value vs Fold change

137 differentially expressed genes
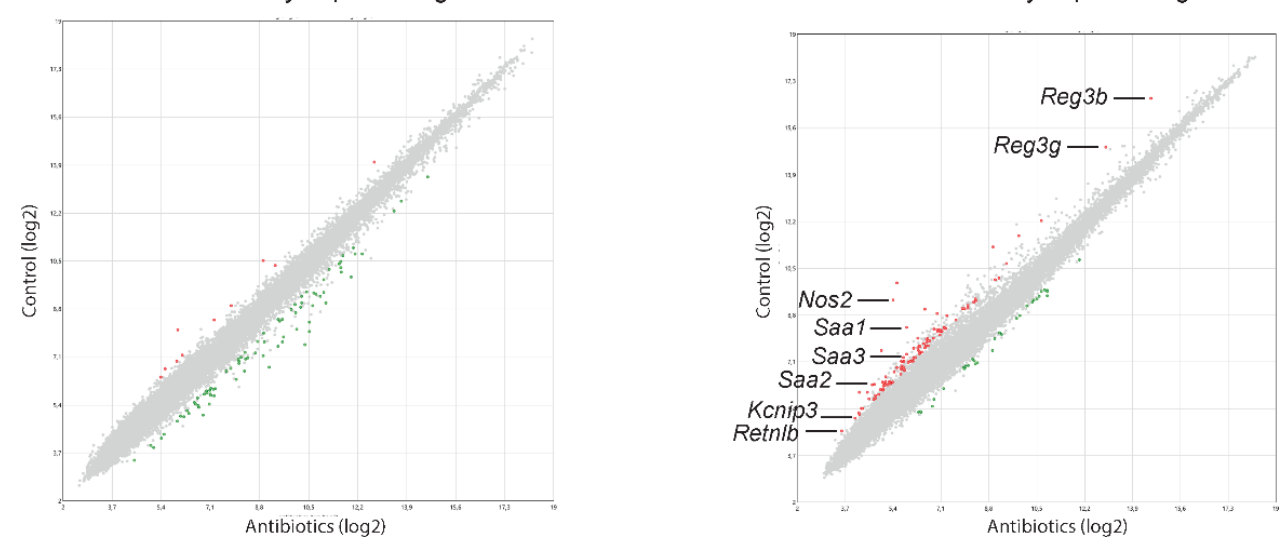

- Upregulated gene - Downregulated gene

Figure 4. Genome-wide gene expression analysis of sorted intestinal epithelial cells. (A) Experimental design of genome-wide gene expression analysis of FACS-sorted intestinal epithelial cells of 8-weekold mice. (B,C) PCA analysis of sorted epithelial cells from 8-week-old proximal (B) and distal (C) small intestine treated with the antibiotic mix or PBS (control) in early life. (D,E) Volcano plots of microarray analysis showing genes differentially expressed between control and antibiotic-treated FACS-sorted intestinal epithelial cells of proximal (D) and distal (E) small intestine of 8-week-old mice. Green dots identify downregulated genes and red dots identify upregulated genes. Statistical analysis by ANOVA eBayes, $p<0.05$ cut-off, $n=4$ samples per group.

2.5. Intestinal Antibacterial Defense Is Reduced in Distal Small Intestine of Adult Mice That Received Antibiotics in Early Life

The identified genes involved in antibacterial defense were downregulated in the distal SI epithelial cells of AB-treated mice compared to control mice at 8 weeks of age (Figure 5A). This is in contrast with our findings at P20 which showed upregulated innate defense markers, including Reg3 lectins, in AB-treated pups [22]. Thus, we then compared the gene expression of these antibacterial defense genes between the distal SI of P20 pups and adult mice. We found that while control adult mice showed a sharp increase in the expression of antibacterial defense genes compared to control neonatal pups (Figure 5B), 
AB-treated adult mice showed similar expression levels of these genes compared to ABtreated neonatal pups (Figure $5 \mathrm{C}$ ). This indicates that the developmental upregulation in gene expression of antibacterial defense markers taking place in the distal SI of control mice does not occur in AB-treated mice.
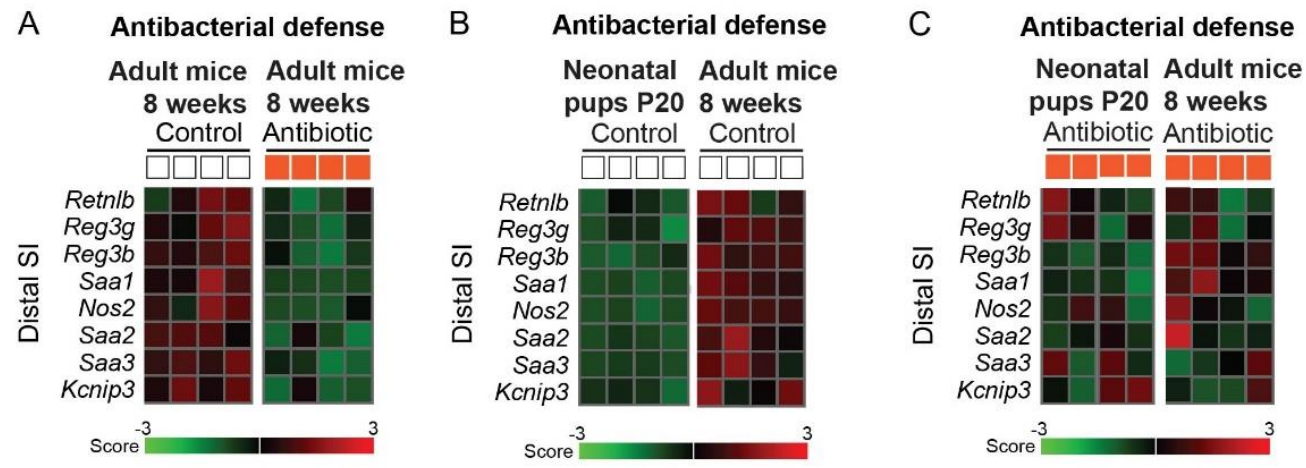

$\mathrm{D}$

Antibacterial defense
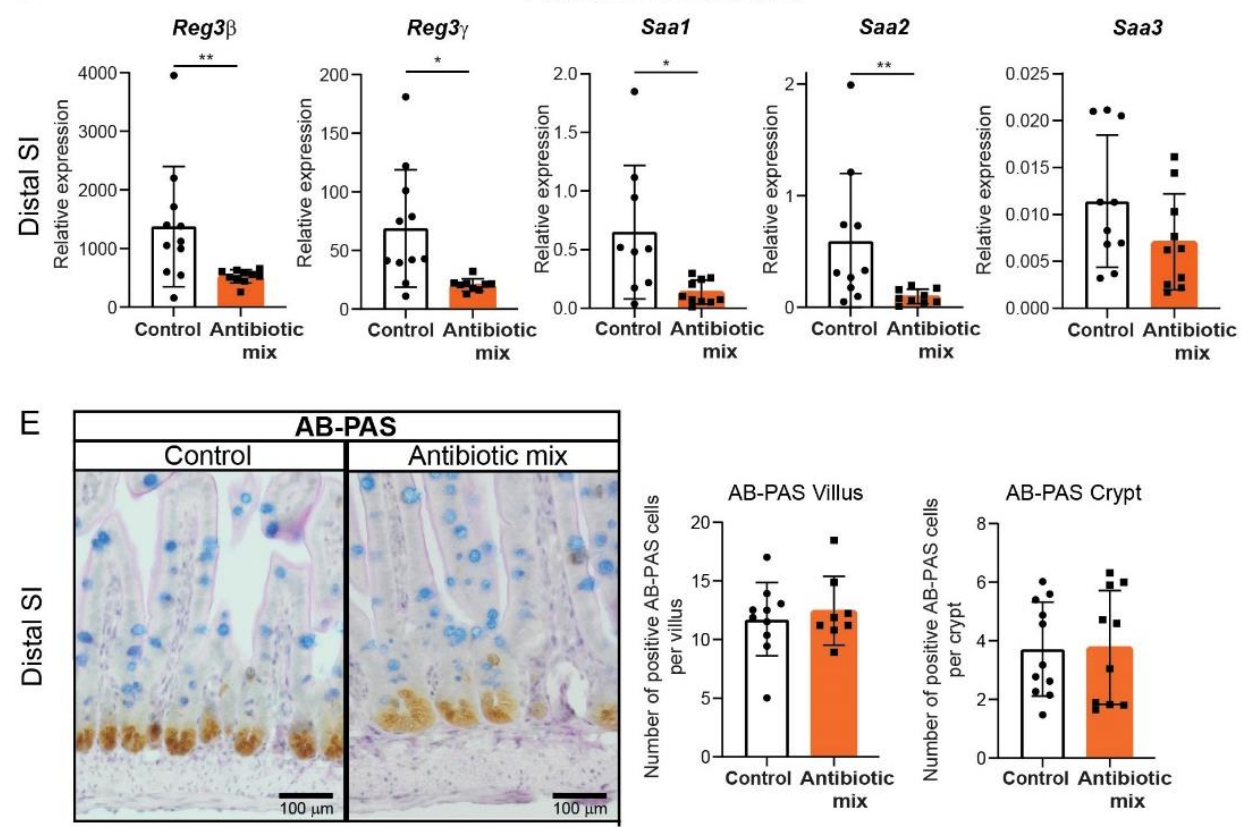

Figure 5. Reduced antibacterial defense in distal small intestine of adult mice treated with early life antibiotics. Differential gene expression analysis of sorted intestinal epithelial cells after antibiotic treatment. (A-C) Curated heatmaps of selected genes from top downregulated and top upregulated genes, based on biological interest and grouped according to function "antibacterial defense" in distal epithelial cells of control and AB-treated adult mice (A), control neonatal pups and adult mice (B), and $A B$-treated neonatal pups and adult mice $(C)$. The colored bar represents the expression level from low (green) to high (red), $n=4$ samples per group. (D) Whole tissue real-time qPCR analysis of antibacterial defense markers $\operatorname{Reg} 3 \beta, \operatorname{Reg} 3 \gamma$, Saa1, Saa2, and Saa3 in distal small intestine. Relative expression to reference genes Rpl4 and Ppib. Reg3 $\beta: n=11$ control mice, $n=10$ AB-treated mice. Reg3 $\gamma: n=11$ control mice, $n=10$ AB-treated mice. Saa1: $n=9$ control mice, $n=10$ AB-treated mice. Saa2: $n=10$ control mice, $n=9$ AB-treated mice. Saa3: $n=10$ control mice, $n=10$ AB-treated mice. (E) Staining and quantification of mucins in villus and crypts of distal small intestine. Villi: $n=10$ control mice, $n=8$ AB-treated mice; crypts: $n=11$ control mice, $n=10$ AB-treated mice. (Scale bars, $100 \mu \mathrm{m}$.) Statistical analysis by ANOVA eBayes, $p<0.05$ cut-off $(\mathbf{A}-\mathbf{C})$ or by one-tailed unpaired $t$-test or Mann-Whitney test (Reg3 $\beta$, Saa2), when data were not normally distributed as assessed by D'Agostino and Pearson normality test (Sct). Error bars indicate the mean $\pm \mathrm{SD}$. Levels of significance are indicated $\left.{ }^{*} p<0.05,{ }^{* *} p<0.01\right)$. 
Colitis is one of the pathologies that has been associated with the use of antibiotics during early life [17-19]. We examined in more detail the expression of regenerating islet-derived protein 3 lectins (Reg3) and serum amyloid A proteins (Saa), as these have been described to be inversely correlated with the development of colitis [33,34]. An independent experiment was performed with exactly the same conditions and whole distal SI was analyzed by qRT-PCR, confirming these results, except for Saa3 (Figure 5D). Finally, visualization of goblet cells, which are key players in gut barrier defense, by staining of mucins, showed a similar number of this secretory cell type between antibiotic-treated and control mice (Figure 5E). Overall, these results showed that early life AB treatment limits intestinal antibacterial defense in the distal small intestine by preventing the normal developmental pattern of these defense genes from weaning into adulthood.

\section{Discussions}

In this study, we found that pre-weaning treatment of young mice with $A B$ results in permanent higher SI weight and increased SI length later in life (Figure 1). This might be partly explained by the crypt hyperproliferation observed in the proximal SI of AB-treated mice, supported by the higher amount of Paneth cells, and the consequent increase in crypt depth (Figures 2 and 3). Certain bacterial strains can influence crypt proliferation. Specifically, Gram-positive bacteria and associated short-chain fatty acids (SCFAs) production are known to increase IECs turnover [35]. Lactic acid-producing bacteria have also been shown to stimulate intestinal stem cell proliferation [36]. Examination of the intestinal bacterial composition before and after $\mathrm{AB}$ treatment, as well as later in life, could provide additional insights into whether the observed increase in SI weight, length, and proliferation is due to microbial signals. Nevertheless, the fact that morphological differences are only evident in the poorly microbial-populated proximal SI compared to the distal SI indicates that these differences might be independent of microbiota.

The strongly reduced intestinal permeability measured at P20 [22] was not observed in adulthood (Figure 1). Decreased permeability, and thus increased barrier function, is one of the hallmarks of intestinal epithelial maturation that in mice occurs between the second and fourth week after birth [37]. The similarity in intestinal permeability observed in adulthood between AB-treated and control mice further demonstrates that its reduction at P20 was a result of the accelerated maturation caused by AB treatment and, thus, an early life effect.

Although the increase in expression of adult brush-border genes was a short-term effect of early life $\mathrm{AB}$ in both SI regions [22], at 8 weeks only Arg2 remained increased in the distal SI of AB-treated mice (Figure 3). Bacteria have been linked to Arg2 expression [38,39], which could explain its specific increase in distal SI at 8 weeks of age. Previous studies have demonstrated that altered microbiota composition induced by AB during early life can persist into adulthood $[12,20,24,40]$. Therefore, it may well be that the microbiota of 8-week-old AB-treated mice is associated with changes in epithelial expression, as we observed for Arg2.

At P20, early life AB treatment induced expression of EEC markers in the proximal SI of both neonatal pups and fetal intestinal organoids, demonstrating that the increase in EEC gene expression and number of EEC is a direct effect of $A B$ on IECs [22]. In AB-treated adult mice, only the expression of Sct remained upregulated, while Cck gene expression, which was not changed at P20, was downregulated (Figure 3). EEC secrete hormones that regulate digestion, epithelial barrier integrity, and mucosal immunity [41]. Inappropriate release of EEC hormones can be involved in the development of obesity and diabetes [42-44]. For example, the marker Sct encodes the hormone secretin which induces insulin release. When insulin levels are persistently high, cells develop insulin resistance, an early sign of type 2 diabetes. In our study, we observed a higher relative gene expression of Sct in AB-treated mice, which could contribute to the AB-linked development of type 2 diabetes [45,46]. However, it is not known whether the increase in Sct relative expression causes continuous increased insulin release and consequently type 2 diabetes development. Moreover, the 
downregulated Cck expression in AB-treated adult mice might have detrimental effects on bacterial growth and intestinal inflammatory conditions. Specifically, decreased Cck might limit the capacity of the gut to prevent bacterial overgrowth and lead to increased translocation of bacteria into the intestinal mucosa [47], which can stimulate pro-inflammatory conditions and exacerbate intestinal inflammation.

Antibacterial defense in the distal SI was the only function still profoundly affected at 8 weeks of age (Figure 5). The expression of antibacterial genes increases from the neonatal stage to adulthood, but AB blocked this increase. The distal SI epithelium is not capable of recovering from the $\mathrm{AB}$ treatment and the antibacterial defense gene expression levels in control adult mice are not reached in $\mathrm{AB}$ adult mice. Thus, not only does the negative impact on the gut microbiome and intestinal immunity caused by early life $A B$ persist in adulthood as described previously $[20,21]$ but also epithelial defense response is affected into adulthood. Consequently, the distal SI of adult mice that received early life AB is less protected at homeostatic conditions, which will leave it more vulnerable to bacterial infections and dysbiosis, thereby increasing the susceptibility to disease. Furthermore, Reg3 lectins, which were among the downregulated antibacterial defense markers, have bactericidal activity against Gram-positive bacteria, controlling their presence in the gut and contributing to the microbiome composition [48-51], and lower Reg3 expression is also associated with a higher risk of colitis in mice [34]. Intestinal chronic inflammation pathologies, such as ulcerative colitis and Crohn's disease, result from inadequate response to intestinal microbiota, including commensal bacteria. Decreased intestinal antibacterial defense due to early life $A B$ treatment can lead to dysbiosis, promoting the onset of inflammatory conditions. Ultimately, bacteria may more easily translocate from the lumen to extraintestinal sites and contribute to the exacerbation of inflammation symptoms. Indeed, adult mice that received AB in early life showed increased susceptibility to DSSinduced colitis, colon cancer, obesity, and diabetes $[11,16,23,40]$. In addition, a recent systematic review of clinical studies in children showed strong evidence for an association between early life $\mathrm{AB}$ and both IBD and celiac disease in later childhood [52]. IBD is a multifactorial disease affecting the gut immune system, epithelium, and microbiome. Previously, it was demonstrated that early life AB causes changes in the microbiome that persist into adulthood, accompanied by a negative impact on the immune system [20,21]. Our present study shows that the epithelial defense response is yet another aspect of the long-lasting effects of $\mathrm{AB}$ in early life. Further studies are required to demonstrate the association between reduced epithelial antibacterial defense and increased predisposition to IBD, and to understand the underlying mechanisms.

In conclusion, early life AB life leads to intestinal structural differences in adulthood, hyperproliferation of the proximal SI, increased Sct and decreased Cck expression in the proximal SI, and impaired antibacterial defense in the distal SI, which may contribute to the increased incidence of gut-related diseases when homeostatic conditions are challenged. Validation of these findings in the human small intestine will help to develop targeted and personalized strategies, for neonates and children that receive prolonged antibiotic treatment, for example using prebiotics, probiotics, or synbiotics.

\section{Materials and Methods}

\subsection{In Vivo Studies}

This study was conducted in accordance with institutional guidelines for the care and use of laboratory animals established by the Animal Ethics Committee of the University of Amsterdam, and all animal procedures related to the purpose of the research were approved under the Ethical license of the national competent authority, securing full compliance the European Directive 2010/63/EU for the use of animals for scientific purposes.

Six pregnant 8 weeks old C57Bl/6J females were obtained from Charles River and were allowed to adapt to the new environment for 1 week. Pregnant females were individually housed and received an AIN-93G diet (Triple A Trading/Altromin, Tiel, Netherlands). Mice were kept in innovive Universal Euro II Type Long disposable mice cages $\left(522.6 \mathrm{~cm}^{2}\right.$ floor 
space, $5653.5 \mathrm{~cm}^{3}$ living space, $12.7 \mathrm{~cm}$ height), with corncob bedding (type $1 / 8$ corncob, Innovive, San Diego, CA, USA) and carton house $(15 \mathrm{~cm} \times 7 \mathrm{~cm} \times 7 \mathrm{~cm}, 25$ Gky irradiated, Tecnilab Des Res, Someren, the Netherlands), with tissue as nesting material (Facial Tissue Extra Soft, PK100ST, King Nederland Tork, Tiel, Netherlands). Cages were cleaned every two weeks. Lights were on at $7 \mathrm{am}$ and off at $7 \mathrm{pm}$ and all procedures occurred during the light phase. The temperature was kept between $20^{\circ} \mathrm{C}$ and $24^{\circ} \mathrm{C}$ and humidity between $45 \%$ and $65 \%$. Food and water (acidified to $2.5-3.0 \mathrm{pH}$, Aquavive ${ }^{\circledR}, \mathrm{M}-\mathrm{WB}-300 \mathrm{~A}$ ) were given ad libitum. Pups were monitored daily from outside the cage for deviations in behavior and physical health, weighted every other day from P10 onwards, and kept with the mothers throughout the experiment. At P10, two experimental groups were randomly defined: treatment group ( 3 litters, 4 pups per litter, 6 females, and 6 males) received daily oral gavage, using a plastic feeding tube (FTP2225, $22 \mathrm{G} \times 25 \mathrm{~mm}$, Instech Solomon, Plymouth Meeting, PA, USA) of $30 \mu \mathrm{L}$ of AB ( $25 \mathrm{mg} / \mathrm{kg} /$ day amoxicillin (Amsterdam UMC, AMC pharmacy, Amsterdam, The Netherlands), $50 \mathrm{mg} / \mathrm{kg} /$ day metronidazole (Amsterdam UMC, AMC pharmacy, Amsterdam, The Netherlands), and $50 \mathrm{mg} / \mathrm{kg} /$ day vancomycin (Sigma-Aldrich, Amsterdam, Netherlands); control group (3 litters, 4 pups per litter (except 1 litter which had 3 pups), 5 females and 6 males) received daily oral gavage of $30 \mu \mathrm{L}$ of PBS. Mice were physically restrained by scruffing (single hand method) during oral gavage. $\mathrm{AB}$ or PBS were consistently given during the light period, always at the same time period of the day, nonblinded. Measurements were performed by a different person in a blinded fashion. For oral gavage, pups were separated from the mother all at once and placed back all at once as well, to correct for differences in maternal care. On P21, pups were weaned and the 6 litters were distributed into 4 different cages: control females $(n=5)$, control males $(n=6)$, antibiotic-treated females $(n=6)$, and antibiotic-treated males $(n=6)$. Mice were monitored daily from outside the cage for deviations in behavior and physical health and weighted every other day. At 8 weeks, mice were fasted and after $3 \mathrm{~h}, 250 \mu \mathrm{L}$ of $60 \mathrm{mg} / 100 \mathrm{gr}$ weight FITC-dextran $4 \mathrm{kDa}$ (Sigma-Aldrich) diluted in PBS were given via oral gavage (plastic feeding tube, Instech Solomon, FTP2225, $22 \mathrm{G} \times 25 \mathrm{~mm}$ ) to all the mice, to assess intestinal permeability. Mice were physically restrained by scruffing (single hand method) during oral gavage. After $4 \mathrm{~h}$, mice were euthanized (one individual at a time) by $100 \% \mathrm{CO}_{2}$ and $4 \%$ isoflurane exposure $(20 \%$ volume $/ \mathrm{min})$ inside a small container. Immediately after, blood was collected by heart puncture in MiniCollect ${ }^{\circledR} Z$ Serum Sep Clot tubes (Greiner, Alphen aan den Rijn, Netherlands). After $30 \mathrm{~min}$ incubation on ice, in the dark, blood was centrifuged and serum was collected and kept at $-80^{\circ} \mathrm{C}$.

\subsection{FITC-Dextran In Vivo Permeability Assay}

Standard samples were obtained by 2-fold serial dilution of $1 \mathrm{mg} / \mathrm{mL}$ FITC-dextran in blood serum. The fluorescence signals of the serum samples were recorded with an excitation wavelength of $485 \mathrm{~nm}$ and emission wavelength of $520 \mathrm{~nm}$ and compared with the standard curve values. The amount of FITC-dextran in serum samples was calculated in $\mathrm{ng} / \mathrm{mL}$.

\subsection{Immunostaining}

Tissue was flushed with PBS, fixed overnight in $4 \%$ formaldehyde, embedded in paraffin, and sectioned. Sections were deparaffinized with xylene and gradually rehydrated in ethanol. After blocking the endogenous peroxidase $\left(0.01 \% \mathrm{H}_{2} \mathrm{O}_{2}\right.$ in methanol), slides were boiled in $0.01 \mathrm{M}$ sodium citrate buffer (pH 6) for $10 \mathrm{~min}$ at $120^{\circ} \mathrm{C}$ in an autoclave for antigen retrieval. Slides were blocked for $30 \mathrm{~min}$ at room temperature in PBS with $1 \%$ bovine serum albumin and $0.1 \%$ Triton- $X-100$. Then, slides were incubated overnight with primary antibody diluted in the blocking buffer. Slides were washed with PBS and secondary antibody diluted in blocking buffer was added for $30 \mathrm{~min}$ at room temperature. Antibody binding was visualized by adding chromagene substrate diaminobenzedine (Sigma-Aldrich, Amsterdam, The Netherlands), sections were counterstained using haema- 
toxillin (Sigma-Aldrich, Amsterdam, The Netherlands) and slides were dehydrated and mounted with entellan.

For Alcian blue and periodic acid (AB-PAS) staining, deparaffinized sections were stained with Alcian blue (Sigma, A3157) for 20 min at room temperature, washed under running tap water for $5 \mathrm{~min}$ and then in bidistilled water before incubating with freshly prepared $0.1 \%$ periodic acid (Sigma, P0430). Slides were then washed once more under running tap water for $10 \mathrm{~min}$ and stained with Schiff's reagent (J62171.AP, VwR International, Amsterdam, The Netherlands) also for $10 \mathrm{~min}$. Slides were washed under running tap water for $5 \mathrm{~min}$ and in bidistilled water for another $5 \mathrm{~min}$. Finally, sections were counterstained with hematoxylin (Sigma) and slides were dehydrated and mounted with entellan. Sections were examined using brightfield microscope Olympus BX51 and analysis was performed with blinded slides. Per mouse, the length of at least 10 villi and the depth of at least 10 crypts were measured. For AB-PAS analysis, at least 20 villi and 40 crypts were quantified. To quantify the number of phosphor-histone H3 and LYZ1 stained cells per crypt, at least 35 crypts in the proximal SI and at least 40 crypts in the distal SI were quantified, per mouse.

Phospho-Histone H3-rabbit polyclonal anti-phospho-histone H3 (1:200, ThermoFischer, PA5-17869).

LYZ1-rabbit polyclonal anti-lysozyme (1:2000, DAKO, A0099).

\subsection{Epithelial Cells FACS-Sorting}

The small intestine of 8-week-old mice was cut open and proximal and distal parts were separated, cut into pieces, and washed with ice-cold PBS. Crypts were dissociated after incubation with $2 \mathrm{mM}$ EDTA (Merck/VWR) for $30 \mathrm{~min}$ at $4{ }^{\circ} \mathrm{C}$ and filtered through a $70 \mu \mathrm{m}$ cell strainer (BD/VWR). Single cells were obtained by incubating crypts with TrypLE Express (Invitrogen). Cells were kept in PBS 2\% FCS Rho-kinase inhibitor and RNase inhibitor (Fermentas/Thermo Fisher Scientific) solution and stained with EpCAM-FITC antibody (1:50, 324204, BioLegend, San Diego, CA, USA) for $30 \mathrm{~min}$ on ice.

\subsection{RNA Isolation and $q R T-P C R$}

For transcriptome profiling, RNA was extracted from EpCAM-positive cells using the phenol-chloroform method. RNA quality was measured on an Agilent 2100 Bioanalyzer.

For qRT-PCR, RNA from whole-tissue tissue was isolated using the Bioline ISOLATE II RNA Mini kit (BIO-52073, Bioline) according to manufacturers' instructions. Then, $1 \mu \mathrm{g}$ of RNA was transcribed using Revertaid reverse transcriptase according to the manufacturer's protocol (Fermentas, Vilnius, Lithuania). Quantitative RT-PCR was performed on a BioRad iCycler using sensifast SYBR No-ROX Kit (GC-biotech Bio-98020) according to the manufacturer's protocol. The two most stable reference genes were determined using GeNorm and their geometric mean was used to calculate the relative expression of genes of interest: for whole-tissue qRT-PCR, ribosomal protein L4 (Rp14) and peptidylpropyl isomerase B (Ppib). Relative gene expression was calculated using N0 values obtained by LinRegPCR analysis. Primers were previously validated using melting curve analyses and gel electrophoresis of PCR products.

Rp14: FW-CCTTCTCCTCTCCCCGTCA ; RV-GCATAGGGCTGTCTGTTGTTT Ppib: FW-GCCAACGATAAGAAGAAGGGA; RV-TCCAAAGAGTCCAAAGACGAC Sis: FW-TGCCTGCTGTGGAAGAAGTAA; RV-CAGCCACGCTCTTCACATTT Arg2: FW-TAGGGTAATCCCCTCCCTGC; RV-AGCAAGCCAGCTTCTCGAAT Lyz: FW-GGATGGCTACCGTGGTGTCAAGC; RV-TCCCATAGTCGGTGCTTCGGTC Reg3 $\beta$ : FW-TGGGAATGGAGTAACAAT; RV-GGCAACTTCACCTCACAT Reg3 $\gamma$ : FW-CCATCTTCACGTAGCAGC; RV-CAAGATGTCCTGAGGGC Gip: FW-AACTGTTGGCTAGGGGACAC; RV-TGATGAAAGTCCCCTCTGCG Gcg: FW-CTTCCCAGAAGAAGTCGCCA; RV-GTGACTGGCACGAGATGTTG Pyy: FW-ACGGTCGCAATGCTGCTAAT; RV-GCTGCGGGGACATCTCTTTTT Sst: FW-GACCTGCGACTAGACTGACC; RV-CCAGTTCCTGTTTCCCGGTG 


\section{Sct: FW-GACCCCAAGACACTCAGACG; RV-TTTTCTGTGTCCTGCTCGCT Cck: FW-GAAGAGCGGCGTATGTCTGT; RV-CCAGAAGGAGCTTTGCGGA ChgA: FW-GTCTCCAGACACTCAGGGCT; RV-ATGACAAAAGGGGACACCAA Saa1: FW-GGTCTTCTGCTCCCTGCTC; RV-AGCAGCATCATAGTTCCCCC Saa2: FW-CAGCCTGGTCTTCTGCTCC; RV-CACATGTCTCCAGCCCCTTG Saa3: FW-AGTAGGCTCGCCACATGTCT; RV-TCCATTGCCATCATTCTTTG}

\subsection{Transcriptome Profiling}

For transcriptome profiling, $400 \mathrm{ng}$ RNA was amplified and labeled using the $3^{\prime}$ IVT Pico Kit Affymetrix RNA Amplification Kit (Nugene) according to the manufacturer's protocol. Microarray analysis of mouse EpCAM-positive cells was performed using the Affymetrix Clariom ${ }^{\circledR}$ S 8-Array HT Plate according to the standard protocols of the Dutch Genomics Service and Support Provider (MAD, Science Park, University of Amsterdam, Netherlands). The data were normalized using Expression Console 1.4.1.46 and uploaded to R2: Genomics Analysis and Visualization Platform (http:/ / hgserver1.amc.nl/, accessed on 28 August 2019). Microarray results were analyzed using R2 software version 3.4.3. Differentially expressed genes were selected based on fold change $(\geq 2)$ in comparison to the control group.

\subsection{Software}

nQuery 7.0 was used for sample-size calculations and ImageJ for villi length and crypt depth measurement. Microarray data was analyzed by Transcriptome Analyses Controle (TAC) and R2. GeNorm was used for identification of most stable reference genes for quantitative Real-time PCR analyses performed by LinRegPCR. GraphPad Prism 8 was used for statistical analyses and graph creation.

\subsection{Statistical Analysis}

Sample size was calculated using nQuery and based on the effect size of maturation studies, using a two-group $t$-test of equal n's, with a significance level $(\alpha)$ of 0.05 and power of $80 \%$. There were no exclusions or drop-outs. Data were analyzed using GraphPad Prism 8 and presented as the mean \pm standard deviation unless stated otherwise in the figure legends. Sample distribution was determined using D'Agostino and Pearson normality test. Sample numbers, experimental replicates, type of statistical analysis test, and $p$ values are reported in the figure legends.

Author Contributions: Conceptualization, T.M.G., R.M.v.E., V.M. and I.B.R.; methodology, T.M.G., M.v.R., S.M., J.K. and M.E.W.; software, T.M.G. and J.K.; validation, T.M.G., M.v.R. and J.L.M.V.; formal analysis, T.M.G.; investigation, T.M.G., M.v.R., J.L.M.V. and S.M.; resources, J.K. and M.v.R.; data curation, T.M.G.; writing-original draft preparation, T.M.G.; writing-review and editing, R.M.v.E., V.M. and I.B.R.; visualization, T.M.G.; supervision, V.M. and I.B.R.; project administration, V.M.; funding acquisition, R.M.v.E., V.M. and I.B.R. All authors have read and agreed to the published version of the manuscript.

Funding: This research was partly funded by Danone Nutricia Research.

Institutional Review Board Statement: This study was conducted in accordance with institutional guidelines for the care and use of laboratory animals established by the Animal Ethics Committee of the University of Amsterdam, and all animal procedures related to the purpose of the research were approved under the Ethical license of the national competent authority, securing full compliance the European Directive 2010/63/EU for the use of animals for scientific purposes.

Informed Consent Statement: Not applicable.

Data Availability Statement: Microarray data are deposited in the Gene Expression Omnibus Database and available upon request.

Conflicts of Interest: Ingrid B. Renes is an employee of Danone Nutricia Research. 


\section{References}

1. Renz, H.; Skevaki, C. Early life microbial exposures and allergy risks: Opportunities for prevention. Nat. Rev. Immunol. 2021, 21, 177-191. [CrossRef] [PubMed]

2. Yassour, M.; Vatanen, T.; Siljander, H.; Hamalainen, A.M.; Harkonen, T.; Ryhanen, S.J.; Franzosa, E.A.; Vlamakis, H.; Huttenhower, C.; Gevers, D.; et al. Natural history of the infant gut microbiome and impact of antibiotic treatment on bacterial strain diversity and stability. Sci. Transl. Med. 2016, 8, 343ra381. [CrossRef] [PubMed]

3. Wang, S.; Egan, M.; Ryan, C.A.; Boyaval, P.; Dempsey, E.M.; Ross, R.P.; Stanton, C. A good start in life is important-perinatal factors dictate early microbiota development and longer term maturation. FEMS Microbiol. Rev. 2020, 44, 763-781. [CrossRef] [PubMed]

4. Stinson, L.F. Establishment of the early-life microbiome: A DOHaD perspective. J. Dev. Orig. Health Dis. 2020, 11, 201-210. [CrossRef]

5. Sturkenboom, M.C.; Verhamme, K.M.; Nicolosi, A.; Murray, M.L.; Neubert, A.; Caudri, D.; Picelli, G.; Sen, E.F.; Giaquinto, C.; Cantarutti, L.; et al. Drug use in children: Cohort study in three European countries. BMJ 2008, 337, a2245. [CrossRef]

6. Fink, G.; D'Acremont, V.; Leslie, H.H.; Cohen, J. Antibiotic exposure among children younger than 5 years in low-income and middle-income countries: A cross-sectional study of nationally representative facility-based and household-based surveys. Lancet Infect. Dis. 2020, 20, 179-187. [CrossRef]

7. Flannery, D.D.; Ross, R.K.; Mukhopadhyay, S.; Tribble, A.C.; Puopolo, K.M.; Gerber, J.S. Temporal Trends and Center Variation in Early Antibiotic Use Among Premature Infants. JAMA Netw. Open 2018, 1, e180164. [CrossRef]

8. Hsia, Y.; Sharland, M.; Jackson, C.; Wong, I.C.K.; Magrini, N.; Bielicki, J.A. Consumption of oral antibiotic formulations for young children according to the WHO Access, Watch, Reserve (AWaRe) antibiotic groups: An analysis of sales data from 70 middle-income and high-income countries. Lancet Infect. Dis. 2019, 19, 67-75. [CrossRef]

9. Ramasethu, J.; Kawakita, T. Antibiotic stewardship in perinatal and neonatal care. Semin. Fetal Neonatal. Med. 2017, 22, 278-283. [CrossRef]

10. Klingenberg, C.; Kornelisse, R.F.; Buonocore, G.; Maier, R.F.; Stocker, M. Culture-Negative Early-Onset Neonatal Sepsis-At the Crossroad Between Efficient Sepsis Care and Antimicrobial Stewardship. Front. Pediatr. 2018, 6, 285. [CrossRef]

11. Schulfer, A.F.; Schluter, J.; Zhang, Y.; Brown, Q.; Pathmasiri, W.; McRitchie, S.; Sumner, S.; Li, H.; Xavier, J.B.; Blaser, M.J. The impact of early-life sub-therapeutic antibiotic treatment (STAT) on excessive weight is robust despite transfer of intestinal microbes. ISME J. 2019, 13, 1280-1292. [CrossRef] [PubMed]

12. Cho, I.; Yamanishi, S.; Cox, L.; Methe, B.A.; Zavadil, J.; Li, K.; Gao, Z.; Mahana, D.; Raju, K.; Teitler, I.; et al. Antibiotics in early life alter the murine colonic microbiome and adiposity. Nature 2012, 488, 621-626. [CrossRef] [PubMed]

13. Cox, L.M.; Yamanishi, S.; Sohn, J.; Alekseyenko, A.V.; Leung, J.M.; Cho, I.; Kim, S.G.; Li, H.; Gao, Z.; Mahana, D.; et al. Altering the intestinal microbiota during a critical developmental window has lasting metabolic consequences. Cell 2014, 158, 705-721. [CrossRef] [PubMed]

14. Nobel, Y.R.; Cox, L.M.; Kirigin, F.F.; Bokulich, N.A.; Yamanishi, S.; Teitler, I.; Chung, J.; Sohn, J.; Barber, C.M.; Goldfarb, D.S.; et al. Metabolic and metagenomic outcomes from early-life pulsed antibiotic treatment. Nat. Commun. 2015, 6, 7486. [CrossRef]

15. Livanos, A.E.; Greiner, T.U.; Vangay, P.; Pathmasiri, W.; Stewart, D.; McRitchie, S.; Li, H.; Chung, J.; Sohn, J.; Kim, S.; et al. Antibiotic-mediated gut microbiome perturbation accelerates development of type 1 diabetes in mice. Nat. Microbiol. 2016, 1, 16140. [CrossRef]

16. Candon, S.; Perez-Arroyo, A.; Marquet, C.; Valette, F.; Foray, A.P.; Pelletier, B.; Milani, C.; Ventura, M.; Bach, J.F.; Chatenoud, L. Antibiotics in early life alter the gut microbiome and increase disease incidence in a spontaneous mouse model of autoimmune insulin-dependent diabetes. PLoS ONE 2015, 10, e0125448. [CrossRef]

17. Ungaro, R.; Bernstein, C.N.; Gearry, R.; Hviid, A.; Kolho, K.L.; Kronman, M.P.; Shaw, S.; van Kruiningen, H.; Colombel, J.F.; Atreja, A. Antibiotics associated with increased risk of new-onset Crohn's disease but not ulcerative colitis: A meta-analysis. Am. J. Gastroenterol. 2014, 109, 1728-1738. [CrossRef]

18. Schulfer, A.F.; Battaglia, T.; Alvarez, Y.; Bijnens, L.; Ruiz, V.E.; Ho, M.; Robinson, S.; Ward, T.; Cox, L.M.; Rogers, A.B.; et al. Intergenerational transfer of antibiotic-perturbed microbiota enhances colitis in susceptible mice. Nat. Microbiol. 2018, 3, 234-242. [CrossRef]

19. Kronman, M.P.; Zaoutis, T.E.; Haynes, K.; Feng, R.; Coffin, S.E. Antibiotic exposure and IBD development among children: A population-based cohort study. Pediatrics 2012, 130, e794-e803. [CrossRef]

20. Zhang, X.S.; Li, J.; Krautkramer, K.A.; Badri, M.; Battaglia, T.; Borbet, T.C.; Koh, H.; Ng, S.; Sibley, R.A.; Li, Y.; et al. Antibioticinduced acceleration of type 1 diabetes alters maturation of innate intestinal immunity. eLife 2018, 7, e37816. [CrossRef]

21. Ruiz, V.E.; Battaglia, T.; Kurtz, Z.D.; Bijnens, L.; Ou, A.; Engstrand, I.; Zheng, X.; Iizumi, T.; Mullins, B.J.; Muller, C.L.; et al. A single early-in-life macrolide course has lasting effects on murine microbial network topology and immunity. Nat. Commun. 2017, 8, 518. [CrossRef] [PubMed]

22. Garcia, T.M.; van Roest, M.; Vermeulen, J.L.M.; Meisner, S.; Smit, W.L.; Silva, J.; Koelink, P.J.; Koster, J.; Faller, W.J.; Wildenberg, M.E.; et al. Early Life Antibiotics Influence In Vivo and In Vitro Mouse Intestinal Epithelium Maturation and Functioning. Cell Mol. Gastroenterol. Hepatol. 2021, 12, 943-981. [CrossRef] [PubMed]

23. Al Nabhani, Z.; Dulauroy, S.; Marques, R.; Cousu, C.; Al Bounny, S.; Dejardin, F.; Sparwasser, T.; Berard, M.; Cerf-Bensussan, N.; Eberl, G. A Weaning Reaction to Microbiota Is Required for Resistance to Immunopathologies in the Adult. Immunity 2019, 50, 1276-1288. [CrossRef] [PubMed] 
24. Miyoshi, J.; Bobe, A.M.; Miyoshi, S.; Huang, Y.; Hubert, N.; Delmont, T.O.; Eren, A.M.; Leone, V.; Chang, E.B. Peripartum Antibiotics Promote Gut Dysbiosis, Loss of Immune Tolerance, and Inflammatory Bowel Disease in Genetically Prone Offspring. Cell Rep. 2017, 20, 491-504. [CrossRef]

25. Olszak, T.; An, D.; Zeissig, S.; Vera, M.P.; Richter, J.; Franke, A.; Glickman, J.N.; Siebert, R.; Baron, R.M.; Kasper, D.L.; et al. Microbial exposure during early life has persistent effects on natural killer T cell function. Science 2012, 336, 489-493. [CrossRef] [PubMed]

26. Scheer, S.; Medina, T.S.; Murison, A.; Taves, M.D.; Antignano, F.; Chenery, A.; Soma, K.K.; Perona-Wright, G.; Lupien, M.; Arrowsmith, C.H.; et al. Early-life antibiotic treatment enhances the pathogenicity of CD4(+) T cells during intestinal inflammation. J. Leukoc. Biol. 2017, 101, 893-900. [CrossRef]

27. Shaw-Smith, C.J.; Walters, J.R. Regional expression of intestinal genes for nutrient absorption. Gut 1997, 40, 5-8. [CrossRef] [PubMed]

28. Anderle, P.; Sengstag, T.; Mutch, D.M.; Rumbo, M.; Praz, V.; Mansourian, R.; Delorenzi, M.; Williamson, G.; Roberts, M.A. Changes in the transcriptional profile of transporters in the intestine along the anterior-posterior and crypt-villus axes. BMC Genom. 2005, 6, 69. [CrossRef]

29. Li, X.; Udager, A.M.; Hu, C.; Qiao, X.T.; Richards, N.; Gumucio, D.L. Dynamic patterning at the pylorus: Formation of an epithelial intestine-stomach boundary in late fetal life. Dev. Dyn. 2009, 238, 3205-3217. [CrossRef]

30. Kayisoglu, O.; Schlegel, N.; Bartfeld, S. Gastrointestinal epithelial innate immunity-regionalization and organoids as new model. J. Mol. Med. 2021, 99, 517-530. [CrossRef]

31. Garcia, T.M.; Navis, M.; Wildenberg, M.E.; van Elburg, R.M.; Muncan, V. Recapitulating Suckling-to-Weaning Transition In Vitro using Fetal Intestinal Organoids. J. Vis. Exp. 2019, 153, e60470. [CrossRef] [PubMed]

32. Schumann, A.; Nutten, S.; Donnicola, D.; Comelli, E.M.; Mansourian, R.; Cherbut, C.; Corthesy-Theulaz, I.; Garcia-Rodenas, C. Neonatal antibiotic treatment alters gastrointestinal tract developmental gene expression and intestinal barrier transcriptome. Physiol. Genom. 2005, 23, 235-245. [CrossRef] [PubMed]

33. Eckhardt, E.R.; Witta, J.; Zhong, J.; Arsenescu, R.; Arsenescu, V.; Wang, Y.; Ghoshal, S.; de Beer, M.C.; de Beer, F.C.; de Villiers, W.J. Intestinal epithelial serum amyloid A modulates bacterial growth in vitro and pro-inflammatory responses in mouse experimental colitis. BMC Gastroenterol. 2010, 10, 133. [CrossRef] [PubMed]

34. Burger-van Paassen, N.; Loonen, L.M.; Witte-Bouma, J.; Korteland-van Male, A.M.; de Bruijn, A.C.; van der Sluis, M.; Lu, P.; van Goudoever, J.B.; Wells, J.M.; Dekker, J.; et al. Mucin Muc2 deficiency and weaning influences the expression of the innate defense genes Reg3beta, Reg3gamma and angiogenin-4. PLoS ONE 2012, 7, e38798. [CrossRef] [PubMed]

35. Park, J.H.; Kotani, T.; Konno, T.; Setiawan, J.; Kitamura, Y.; Imada, S.; Usui, Y.; Hatano, N.; Shinohara, M.; Saito, Y.; et al. Promotion of Intestinal Epithelial Cell Turnover by Commensal Bacteria: Role of Short-Chain Fatty Acids. PLoS ONE 2016, 11, e0156334. [CrossRef]

36. Lee, Y.S.; Kim, T.Y.; Kim, Y.; Lee, S.H.; Kim, S.; Kang, S.W.; Yang, J.Y.; Baek, I.J.; Sung, Y.H.; Park, Y.Y.; et al. Microbiota-Derived Lactate Accelerates Intestinal Stem-Cell-Mediated Epithelial Development. Cell Host Microbe 2018, 24, 833-846.E6. [CrossRef]

37. Arevalo Sureda, E.; Westrom, B.; Pierzynowski, S.G.; Prykhodko, O. Maturation of the Intestinal Epithelial Barrier in Neonatal Rats Coincides with Decreased FcRn Expression, Replacement of Vacuolated Enterocytes and Changed Blimp-1 Expression. PLoS ONE 2016, 11, e0164775. [CrossRef]

38. Gookin, J.L.; Stauffer, S.H.; Stone, M.R. Induction of arginase II by intestinal epithelium promotes the uptake of L-arginine from the lumen of Cryptosporidium parvum-infected porcine ileum. J. Pediatr. Gastroenterol. Nutr. 2008, 47, 417-427. [CrossRef]

39. Talavera, M.M.; Nuthakki, S.; Cui, H.; Jin, Y.; Liu, Y.; Nelin, L.D. Immunostimulated Arginase II Expression in Intestinal Epithelial Cells Reduces Nitric Oxide Production and Apoptosis. Front Cell Dev. Biol. 2017, 5, 15. [CrossRef]

40. Ozkul, C.; Ruiz, V.E.; Battaglia, T.; Xu, J.; Roubaud-Baudron, C.; Cadwell, K.; Perez-Perez, G.I.; Blaser, M.J. A single early-in-life antibiotic course increases susceptibility to DSS-induced colitis. Genome Med. 2020, 12, 65. [CrossRef]

41. Goldspink, D.A.; Reimann, F.; Gribble, F.M. Models and Tools for Studying Enteroendocrine Cells. Endocrinology 2018, 159, 3874-3884. [CrossRef]

42. Crooks, B.; Stamataki, N.S.; McLaughlin, J.T. Appetite, the enteroendocrine system, gastrointestinal disease and obesity. Proc. Nutr. Soc. 2021, 80, 50-58. [CrossRef] [PubMed]

43. McCauley, H.A. Enteroendocrine Regulation of Nutrient Absorption. J. Nutr. 2020, 150, 10-21. [CrossRef] [PubMed]

44. Posovszky, C.; Wabitsch, M. Regulation of appetite, satiation, and body weight by enteroendocrine cells. Part 2: Therapeutic potential of enteroendocrine cells in the treatment of obesity. Horm. Res. Paediatr. 2015, 83, 11-18. [CrossRef] [PubMed]

45. Mikkelsen, K.H.; Allin, K.H.; Knop, F.K. Effect of antibiotics on gut microbiota, glucose metabolism and body weight regulation: A review of the literature. Diabetes Obes. Metab. 2016, 18, 444-453. [CrossRef] [PubMed]

46. Mikkelsen, K.H.; Knop, F.K.; Frost, M.; Hallas, J.; Pottegard, A. Use of Antibiotics and Risk of Type 2 Diabetes: A Population-Based Case-Control Study. J. Clin. Endocrinol. Metab. 2015, 100, 3633-3640. [CrossRef] [PubMed]

47. Wang, X.; Soltesz, V.; Axelson, J.; Andersson, R. Cholecystokinin increases small intestinal motility and reduces enteric bacterial overgrowth and translocation in rats with surgically induced acute liver failure. Digestion 1996, 57, 67-72. [CrossRef]

48. Cash, H.L.; Whitham, C.V.; Behrendt, C.L.; Hooper, L.V. Symbiotic bacteria direct expression of an intestinal bactericidal lectin. Science 2006, 313, 1126-1130. [CrossRef]

49. Lehotzky, R.E.; Partch, C.L.; Mukherjee, S.; Cash, H.L.; Goldman, W.E.; Gardner, K.H.; Hooper, L.V. Molecular basis for peptidoglycan recognition by a bactericidal lectin. Proc. Natl. Acad. Sci. USA 2010, 107, 7722-7727. [CrossRef] 
50. Mukherjee, S.; Zheng, H.; Derebe, M.G.; Callenberg, K.M.; Partch, C.L.; Rollins, D.; Propheter, D.C.; Rizo, J.; Grabe, M.; Jiang, Q.X.; et al. Antibacterial membrane attack by a pore-forming intestinal C-type lectin. Nature 2014, 505, 103-107. [CrossRef]

51. Vaishnava, S.; Yamamoto, M.; Severson, K.M.; Ruhn, K.A.; Yu, X.; Koren, O.; Ley, R.; Wakeland, E.K.; Hooper, L.V. The antibacterial lectin RegIIIgamma promotes the spatial segregation of microbiota and host in the intestine. Science 2011, 334, 255-258. [CrossRef] [PubMed]

52. Kamphorst, K.; van Daele, E.; Vlieger, A.M.; Daams, J.G.; Knol, J.; van Elburg, R.M. Early life antibiotics and childhood gastrointestinal disorders: A systematic review. BMJ Paediatr. Open 2021, 5, e001028. [CrossRef] [PubMed] 